\title{
Climate change impacts on agriculture sector: A case study of Pakistan
}

\author{
Uzair Ali ${ }^{1}$ (D) Wang Jing ${ }^{*}$ Jialin Zhu' ${ }^{1}$ Zhibek Omarkhanova ${ }^{2}$ Shah Fahad $^{3}$ \\ Zhanar Nurgazina' ${ }^{1}$ (D) Zaid Ashiq Khan ${ }^{1}$
}

${ }^{1}$ College of Economics and Management, Northwest A\&F University Yangling, Shaanxi 712100, PR, China. E-mail: wangjing660113@yeah.net. ${ }^{*}$ Corresponding author.

${ }^{2}$ Department of Finance S.Seifullin Kazakh Agro technical University Astana, Kazakhstan.

${ }^{3}$ School of Management, Xi'an Jiaotong University, Xi'an, China.

ABSTRACT: The current article looks at the effects of climate change on agriculture, especially crop production, and influence factors of agricultural development in terms of their rational use in Pakistan. Due to the dependence of economic development, and agriculture in the South Asian region on access to renewable national resources and the associated vulnerability to climate change, the limited financial and professional resources of the Islamic Republic of Pakistan require a clear definition of national priorities in this area. In the preparation of this article, general scientific cognition methods, in particular, empirical-theoretical methods were used. Grouping and classification methods have been used to process and systematize the data. The ability to change productivity, depending on the variation of the average annual air temperature and the average annual precipitation rate, was considered using a two-factor regression model. The main finding of the study is that temperature and precipitation have a negative impact on agricultural production. This study can provide a scientific justification for the specialization of agricultural production in the regions of Pakistan as well as the execution of the necessary agricultural activities.

Key words: agriculture, climatic conditions, agriculture economy, stabilization, grain crops, crop production.

Impactos das mudanças climáticas no setor agrícola: um estudo de caso do Paquistão

RESUMO: $O$ objetivo deste artigo é examinar os efeitos das mudanças climáticas na agricultura, especialmente a produção agrícola e os fatores de influência do desenvolvimento agrícola em termos de uso racional no Paquistão. Devido à dependência do desenvolvimento econômico e da agricultura na região do sul da Ásia do acesso a recursos nacionais renováveis e à vulnerabilidade associada às mudanças climáticas, os recursos financeiros e profissionais limitados da República Islâmica do Paquistão exigem uma definição clara das prioridades nacionais nessa área. Na preparação deste artigo, foram utilizados métodos gerais de cognição científica, em particular métodos teóricoempíricos. Os métodos de agrupamento e classificação foram utilizados para processar e sistematizar os dados. A capacidade de alterar a produtividade, dependendo da variação da temperatura média anual do ar e da taxa média anual de precipitação, foi considerada usando um modelo de regressão de dois fatores. A principal descoberta do estudo é que a temperatura e a precipitação têm um impacto negativo na produção agrícola. Este estudo pode fornecer uma justificativa científica para a especialização da produção agrícola nas regiões do Paquistão, bem como a execução das atividades agrícolas necessárias.

Palavras-chave: agricultura, condições climáticas, economia agrícola, estabilização, colheita de grãos, produção agrícola.

\section{INTRODUCTION}

The Islamic Republic of Pakistan feels the need to find solutions to issues such as obtaining objective and unbiased assessments of climate changes in its territory, including assessing the role of the anthropogenic factor in current and upcoming climate changes, assessing the impact of climate change on the agricultural sector of the economy and the social sphere. Therefore, the integrated impact of agricultural risks obliges producers to put stability and a guaranteed result to the first position in the system of their interests (POINTNER \& RITZBERGERGRÜNWALD, 2019).

Agricultural production is characterized by a special risky environment, as it presents natural and climatic risks, which are dangerous and highly affect the final results of the activity (CHANDIO et al., 2020b). Moreover, the economic damage they cause is not only comparable to the scale of 
the financial results of commodity producers but periodically exceeds them. Farms also suffer losses as a result of exposure of traditional for any commercial activity risks (production, marketing, financial): the size of these losses is large, difficult to assess, and the consequences are fatal (STOEFFLER et al., 2020).

A rare and constantly decreasing network of stations sharp differences in the hydrometeorological regime of individual regions of the state and the absence of microclimatic significantly complicates the task of assessing resources by traditional methods and approaches, making it impossible in some areas. The vulnerability of the region is even more aggravated by the inefficient use of resources, outdated infrastructure, low practical application of relevant standards and norms, as well as the poor condition of ecology and high levels of pollution (SHAH \& PARK, 2020). The importance of agriculture in the economies of different countries is different, but with the growth of GDP per capita and structural changes in the economy, the share of agriculture decreases, which is predictable. In some of the world's poorest countries, agriculture accounts for more than $30 \%$ of economic activity, and in general for the group of least developed countries - $27 \%$ of GDP. Pakistan is small compared to India with respect to the agriculture sector FAO, (2018) and low energy production compared to neighboring Iran (BANK, 2015). Its "natural wealth" is a favorable geostrategic position, which made Pakistan as a connecting link between the regions of the Middle East, Central, and South Asia (KHETRAN, 2016). However, to make this a necessary condition for turning Pakistan into an important center of cooperation and development of the region, the creation of a developed infrastructure is required. The solution to such a large-scale task requires time and great effort. Agriculture is one of the key industries in Pakistan. The main crop of the country is wheat (JANJUA et al., 2014) (Table 1).

The agricultural sector of Pakistan is facing the issue of irrigation facilities (CHANDIO et al., 2020a). Approximately $70 \%$ of the sown area is irrigated. The main area of agriculture is irrigated from wells, dams, canals, and rivers. Many new projects of irrigation are still under construction, which would help in the future to irrigate Pakistan's agricultural system (KAHLOWN \& MAJEED, 2003). The development of the agriculture sector is imperative in any country, particularly in Pakistan because it plays a major role in the socio-economic stability of the country. However, climate change is the most important, vulnerable, and sensitive factor for the agriculture sector (ALI et al., 2020). Thus, climate change has a negative impact on the growth, maturation, and yield of cotton plants and the lives of farmers.

The rational use of the wealth and diversity of the country's climatic conditions, including changing conditions, is the key to its stable development (ZHU et al., 2004). There is considerable uncertainty in the quantitative estimates of how the expected climate changes will proceed in the future and which impact they will have on ecosystems, economic activities, and social processes in different countries and regions, including Pakistan. Both positive and negative consequences are possibly depending on the level of development of the region and its climate (ZAIED \& CHEIKH, 2015). Unfortunately, the accuracy of existing climate forecasts is low today. None of the models can fully simulate the climate. Due to the significant uncertainty of climate forecasts noted

Table 1 - World ranking position of Pakistan.

\begin{tabular}{lcc}
\hline No & Agricultural production & World ranking position \\
\hline 1 & Chickpea & $2^{\text {nd }}$ in the world \\
\hline 2 & Apricots & $4^{\text {th }}$ \\
3 & Cotton & $4^{\text {th }}$ \\
\hline 4 & Sugarcane & $4^{\text {th }}$ \\
\hline 5 & Onions & $5^{\text {th }}$ \\
\hline 6 & Dates & $6^{\text {th }}$ \\
\hline 7 & Mango & $7^{\text {th }}$ \\
\hline 9 & Tangerines & $8^{\text {th }}$ \\
\hline 10 & Rice & $8^{\text {th }}$ \\
\hline 11 & Wheat & $9^{\text {th }}$ \\
\hline & Oranges & $10^{\text {th }}$ \\
\hline
\end{tabular}

Ciência Rural, v.51, n.8, 2021. 
above, the range of estimates of the possible economic consequences of climate warming remains wide.

To rescue the production system and the growth of potential damage from natural disasters is a need for developing economic research and assessment of the use of climate information. Considering the importance of the agricultural sector in the country's economy and its dependence on natural and climatic conditions, insurance in crop production was classified as mandatory. In addition, agricultural production is at risk of natural disasters and emergencies. Natural hazards such as drought, hail, heatwaves, and floods can lead to serious production losses (SARKER et al., 2012; PRAVEEN \& SHARMA, 2019; ALI et al., 2020; CHANDIO et al., 2020c; MALASHIKHINA N.N. 2014).

Since Pakistan is located in a high-risk agricultural area, where the average annual drought rate is $40 \%$, and in some regions of the country reaches $60 \%$, the problem of frequent adverse weather events is further complicated by their systemic nature, when droughts affect vast areas of the country's agricultural land, and they can lead to massive losses for agricultural producers. The consequences of adverse weather conditions also affect the financial stability and solvency of agricultural producers. According to KISELEVA (2003) in her publications on stabilizing the financial situation of agricultural enterprises, many factors, in particular, climatic conditions influenced the indicators of declining productivity. Simultaneously, weather risk is superimposed on economic risk, which makes it difficult to identify and analyze it. KURMANBAEV and ALIBAEVA (2015) in their articles reported that it is necessary to identify effective ways to reduce agricultural risks, which are conducted on the basis of the development of scientifically based recommendations and require knowledge of the structure and sources of financial support provided by equipment, crop protection products, financial guaranties of insurance coverage. The impact on risk by insurance means that other methods do not fully compensate for the possible damage and losses from various risks.

The barriers that are facing Pakistan in the agricultural sector are mismanagement of resources, technological issues, low investment, infrastructure, agricultural trade issues, and an acute shortage of electricity and energy problems (JANJUA et al., 2014; ALI et al., 2020). These problems have been complemented by the severe ongoing climate change, drought, and floods. Serious prediction of such extreme weather events can become more frequent and serious in Pakistan as a result of climate change. As the temperature continues to rise, and precipitation continues to change, water will become an increasingly scarce resource for farmers, which threatens the food security and livelihoods of farmers in the Indus basin, as well as general food security in Pakistan (KAMENEV S.N. 2014). The objectives of this study are two-fold. First, this study checks the impact of change in temperature on the agricultural sector in Pakistan. Second, this study determines the influences of changes in precipitation on the agriculture sector in Pakistan. The rest of the paper is organized as follows. The next section is the materials and methods. The third section is results and discussion. The final section is about the conclusion of the manuscript.

\section{MATERIALS AND METHODS}

Pakistan is an agrarian country. Therefore, agriculture is the basic component of the economy of Pakistan, whose share in the country's GDP at this moment is approximately $25 \%$ and provides employment for approximately $45 \%$ of the country's working population. If we consider the dynamics of agricultural development since 1999, the development trend was different each time (Table 2 and Figure 1).

So, for example, this national natural disaster affected approximately 21 million people at the end of 2010. The main problems for populating the country were associated with a growing shortage of food and drinking water and the spread of various diseases. Accordingly, during this period, due to climate change, there was a sharp decline in agricultural development in Pakistan.

In 2015-2016, northern Pakistan was affected due to clashes and armed operations. As a result, the livelihood of a massive population suffered. For rehabilitation, many international level project was launched in the territory for reducing economic inequality. As a result of this project, agricultural production was increased. The demand for agricultural products is increasing due to the rapid growth of the population in Pakistan. Therefore, the government is taking a step to increase crop yields, controlling the prices of fertilizers and pesticides (GOP, 2017d). Moreover, the government has taken measured to support farming, including concessional lending and priority investment projects, budget subsidies to the agricultural provinces of Punjab and Sindh, subsidized interest rates on loans, loan insurance, and reimbursement of leasing payments for processing equipment for farmers contributed to the widespread development of agriculture under consideration period (GOP, 2012, GOP, 2017). 
Table 2 - Average annual agricultural growth rate in Pakistan (\%).

\begin{tabular}{|c|c|c|}
\hline No & Year & The average annual growth rate of agriculture \\
\hline 1 & 1999-2000 & 6.1 \\
\hline 2 & $2000-2001$ & -2.2 \\
\hline 3 & $2001-2002$ & 1 \\
\hline 4 & $2002-2003$ & 4.1 \\
\hline 5 & 2003-2004 & 2.4 \\
\hline 6 & 2004-2005 & 6.5 \\
\hline 7 & 2005-2006 & 6.3 \\
\hline 8 & 2006-2007 & 4.1 \\
\hline 9 & 2007-2008 & 1 \\
\hline 10 & 2008-2009 & 4 \\
\hline 11 & $2009-2010$ & 0.5 \\
\hline 12 & 2010-2011 & 1.2 \\
\hline 13 & 2011-2012 & 3.5 \\
\hline 14 & $2012-2013$ & 3.3 \\
\hline 15 & 2013-2014 & 3.6 \\
\hline 16 & 2014-2015 & 3.2 \\
\hline 17 & 2015-2016 & 0.2 \\
\hline 18 & 2016-2017 & 3.5 \\
\hline
\end{tabular}

Note - Compiled on the basis of source:

(GOP, 2005 ), (GOP, 2013), (GOP, 2017c).

These data show that those years from 2012-2013 to 2016-2017, since the fiscal year in Pakistan does not coincide with the calendar year and begins on July 1 of this year, and ends next year on June 30 . Table 3 presents that at the end of 2016-2017, the volume of agricultural production increased by $3.5 \%$, which is significantly higher than the growth rate of $0.3 \%$ observed a year earlier.

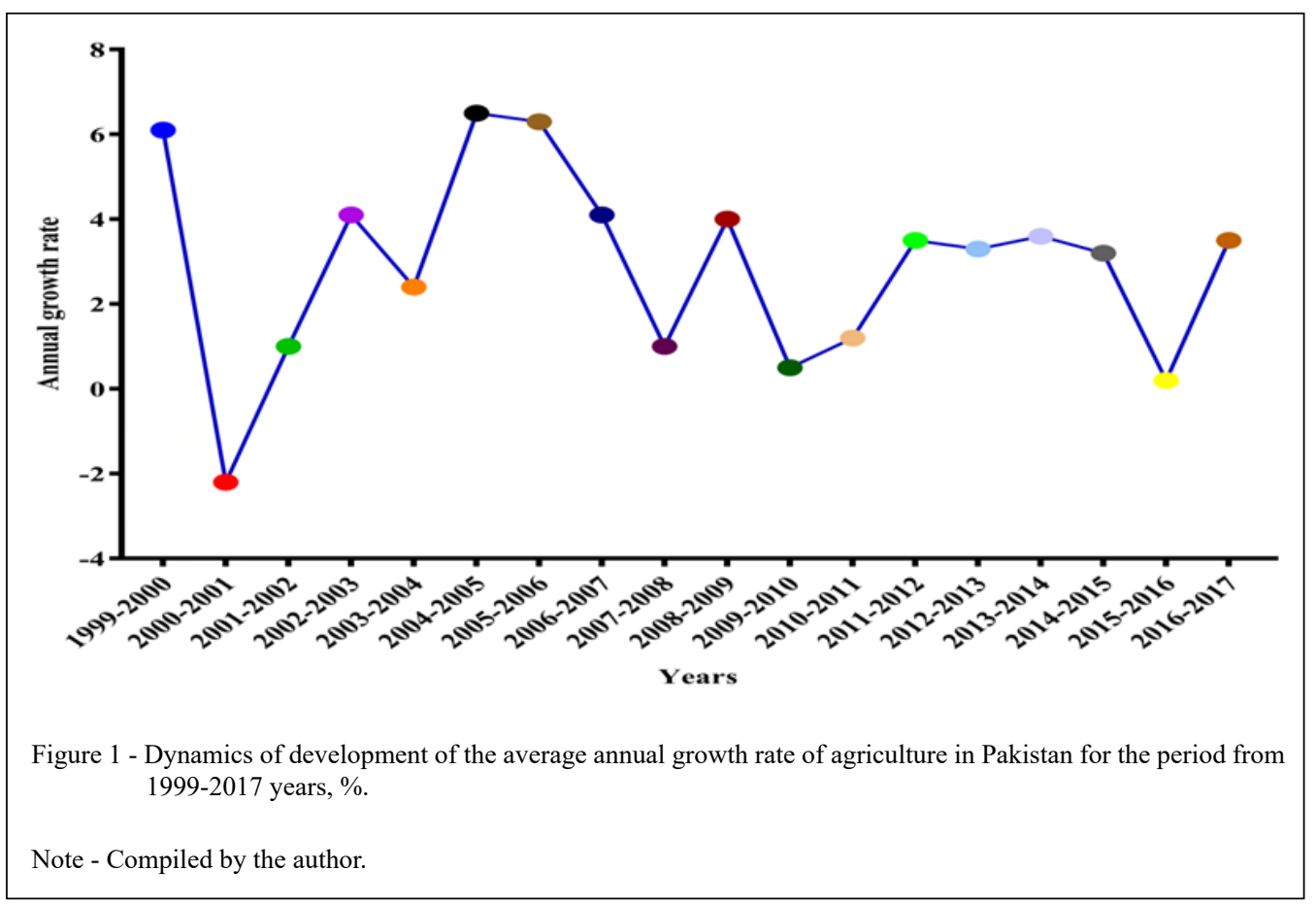

Ciência Rural, v.51, n.8, 2021. 
Table 3 - Rostselsko-economic sector of the economy in 2012 - 2017 financial years.

\begin{tabular}{lcccccc}
\hline Economic sector & $2012-2013$ & $2013-2014$ & $2014-2015$ & $2015-2016$ & $2016-2017$ & Share in GDP \\
\hline Agriculture & 3.3 & 3.6 & 3.2 & -0.2 & 3.5 & 19.5 \\
Major cultures & 1.2 & 8.0 & 0.3 & -7.2 & 4.1 & 4.7 \\
Minor cultures & 6.1 & 5.4 & 1.1 & -0.3 & 0.2 & 2.2 \\
Animal husbandry & 3.5 & 2.8 & 4.1 & 3.6 & 3.4 & 1.2 \\
Fishing & 0.7 & 1.0 & 5.8 & 3.2 & 0.4 \\
Forestry & 1.0 & -6.7 & 3.2 & 8.8 & 14.5 \\
\hline
\end{tabular}

Note - Compiled from the source data of the Pakistan Bureau of Statistics for 2012-2017.

Despite the reduction in the area of cultivated land for the first time in the last decade, it has been possible to increase agricultural production in all major crops (GOP, 2017b).

Cotton production grew by $7.6 \%$ in absolute terms, amounting to 10.6 million bales; the yield of sugar cane and corn allowed to collect 73.6 million tons $(+12.4 \%)$ and 6.1 million tons $(+$ $16.3 \%)$, respectively. Minor growth in production volumes was noted for wheat $(+0.5 \%, 25.7$ million tons) and rice ( $+0.7 \%, 6.8$ million tons). Among nonmain crops, growth was recorded in the cultivation of peas $(+25.5 \%)$ and beans $(+27.4 \%)$, onions $(+$ $2.7 \%)$ and chili pepper $(+0.2 \%)$. Simultaneously, the volumes of barley, rapeseed, lentils, tobacco, potatoes, and fruits fell. Livestock, a prerequisite for Pakistan's growing economy, accounted for $11.4 \%$ of Pakistan's agricultural output. The government of Pakistan supports the livestock sector. The growth of agricultural production in livestock amounted to $3.4 \%$, at the end of 2017 . The number of cattle (cows and buffaloes) amounted to 82.1 million heads, goats and sheep - 102.3 million heads, donkeys - 5.2 million heads. Poultry farming is one of the fastest-growing agricultural sectors in Pakistan, providing $7.1 \%$ of the agricultural sector. 1.5 million Pakistanis are employed in the cultivation of 85.6 million poultry stocks. At the end of 2016-2017, the cost of poultry products amounted to 162.8 billion Pakistani rupees.

Despite the modest contribution of fisheries to Pakistan's GDP $(0.41 \%)$, this sector is a stable source of foreign exchange earnings to the budget. At the end of 2017, 520000 million tons of fish were caught, of which one-fifth was exported (\$ 276.2 million) (GOP, 2017a). Pakistan is exporting various commodities to different countries of the world. The major commodities of Pakistani exports in agriculture are rice, wheat, cotton, sugarcane, corn. The minor crops include legumes, onions, potatoes, tomatoes, cucumbers, and other vegetables and fruits. Together, they form up to $80 \%$ of total exports (Figures 2 and 3) (GOP, 2017b).

The export of goods and services consists of sales, barter, gifts and grants, and services from residents to nonresidents. The processing of exports and imports in SNA coincides with the indicator in the balance of payments accounts, as described in the Balance of Payments Manual (Table 4) (GOP, 2011).

Although historically the most fertile lands (at the same time the most convenient for construction) reported themselves within urban agglomerations, the main reason for the loss of fertile lands is their degradation due to water and wind erosion, , which is illustrated in table 5 (PAPTSOV, 2018).

Let analyze how the change in climatic conditions affects the yield of grain crops. For this, we compiled table 6 , which presents data on cereal production and their changes for the period from 2006-2017 (WWW. HIKERSBAY).

A graphical representation of the monthly change in climate data for temperature and precipitation affecting cereal production is shown in figure 4 (PAKISTAN, 2017).

The difference between the rainfall and the driest and the wettest month is $81 \mathrm{~mm}$. The temperature varies throughout the year by $12.0{ }^{\circ} \mathrm{C}$. For each month, you will find data on precipitation $(\mathrm{mm})$, average, maximum and minimum temperature (in degrees Celsius and Fahrenheit). The first line shows the name of the months starting from January until the end of December.

Figures 5, 6, 7 show the statistical data necessary for constructing a two-factor regression model (SIKAN, 2007; BATES, et al., 2008; PAKISTAN, 2017). 


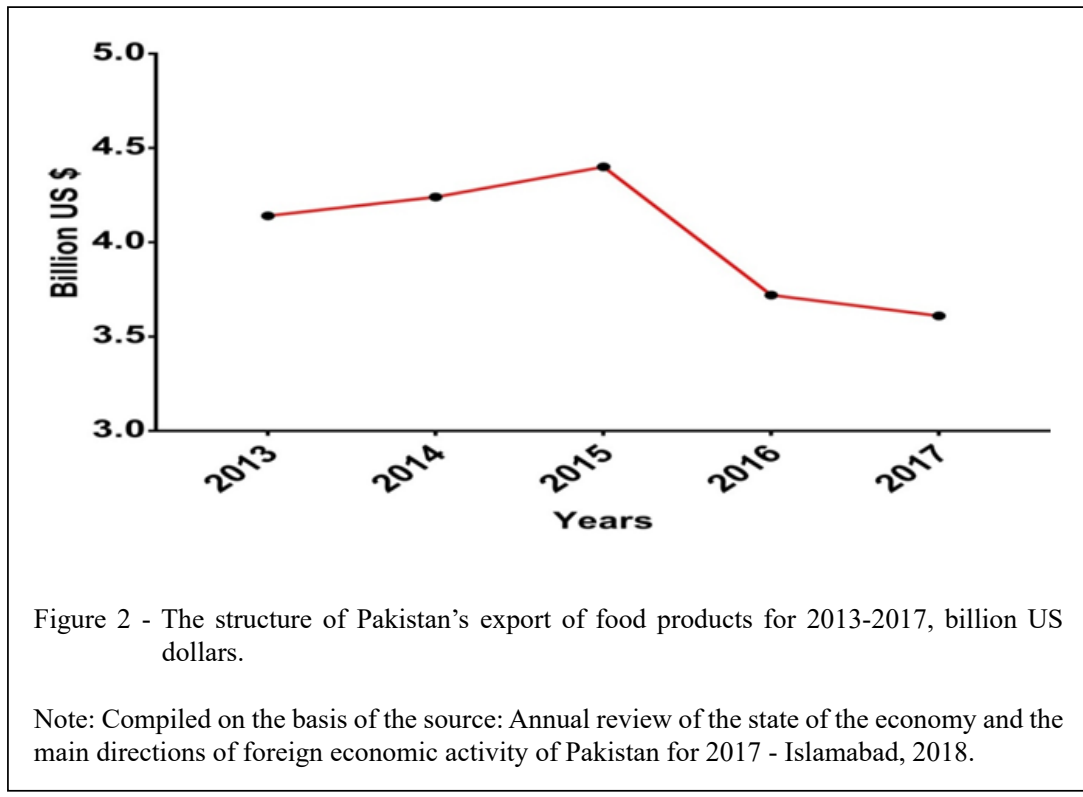

Since the time series of the average annual air temperature and the average annual amount of precipitation is subject to fluctuations, we first perform exponential smoothing of these indicators (we take the smoothing parameter to be 0.3 ). We introduce and take $y$-Crop yield of grain (thousand tons), $x_{1}$
- Average air temperature $\left(\mathrm{C}^{0}\right), x_{2}$ - The number of precipitation (mm.) (SEDELEV, 2009). We evaluated the parameters of the two-factor regression equation using the Regression analysis tool (Data Analysis in Excel). As a result of data approximation, the following multiple linear regression equation was obtained:

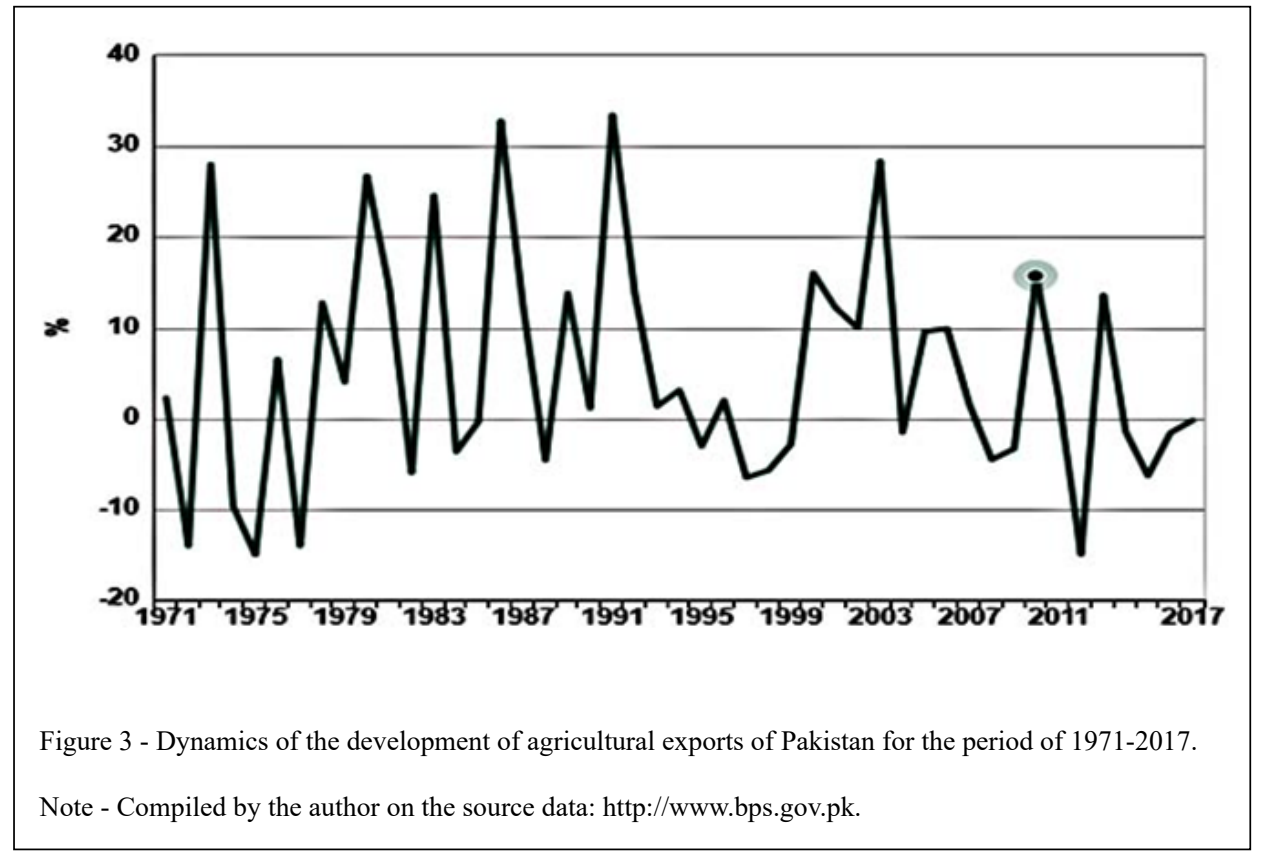

Ciência Rural, v.51, n.8, 2021. 
Table 4 - The impact of exports on agriculture.

\begin{tabular}{|c|c|c|}
\hline Year & Value & Change, $\%$ \\
\hline 2017 & -0.2 & $-86.03 \%$ \\
\hline 2016 & -1.6 & $-74.73 \%$ \\
\hline 2015 & -6.3 & $328.57 \%$ \\
\hline 2014 & -1.5 & $-110.90 \%$ \\
\hline 2013 & 13.6 & $-190.53 \%$ \\
\hline 2012 & -15.0 & $-732.36 \%$ \\
\hline 2011 & 2.4 & $-84.90 \%$ \\
\hline 2010 & 15.7 & $-567.33 \%$ \\
\hline 2009 & -3.4 & $-26.16 \%$ \\
\hline 2008 & -4.6 & $-401.52 \%$ \\
\hline 2007 & 1.5 & $-84.74 \%$ \\
\hline 2006 & 9.9 & \\
\hline
\end{tabular}

Note - Compiled on the basis of the source data: http://www.bps.gov.pk.

$y=294148.038-10580.690 x_{1}-47.686 x_{2}$

The multiple correlation coefficient is equal $\mathrm{R}=0.78$, which indicates a close relationship between the resulting trait and two-factor traits at the same time. Results of the regression analysis show that the observed value of the Fisher criterion is equal to $\mathrm{F}_{\mathrm{obs}}=6.369$. The critical value of the Fisher criterion at the significance level $\alpha=0.05$ and the number of degrees of freedom $k_{1}=m=2, k_{2}=n-m$ $1=8$ (where $\mathrm{n}$ is the number of observations, $\mathrm{m}$ is the number of factors) are equal to $F_{\text {crit }}(0.05 ; 2 ; 9)=4.459$. Since $\mathrm{F}_{\text {obs }}>\mathrm{F}_{\text {crit }}(6.369>4.459)$, we can conclude about the statistical significance and reliability of the obtained regression equation. The coefficients present that an increase in the average annual air temperature by 1 , the grain yield will decrease by $10,580.69$ thousand tons. An additional $1 \mathrm{~mm}$ drawnout precipitation also reduces productivity by 47.686 thousand tons. One of the indicators with which you can evaluate the measure of the response of one variable to a change in another is the coefficient of elasticity. In this patient, it will show the ability of the crop to change depending on changes in the average annual air temperature and the average annual rate of precipitation. We define the aggregate averages of elasticity coefficients:

$$
E_{y x_{1}}=-6.19 \%, \quad E_{y x_{2}}=-0.59 \%
$$

The elasticity coefticients show that an increase in air temperature by $1 \%$ from the average level, productivity decreases by $6.19 \%$ from its average level with a constant amount of precipitation. Further, with an increase in the amount of precipitation by $1 \%$ of the average level, the yield decreases by $0.59 \%$ of its average level at constant air temperature. The main reason for the degradation of farmland, most strongly associated with global climate change, is water and wind soil erosion (MAAS, A., et al. 2011).

\section{RESULTS AND DISCUSSIONS}

The results of the study have been explained in this section. First, increase in air temperature by $1 \%$ from the average level, productivity decreases by $6.19 \%$ from its average

Table 5 - Indicators of degradation of farmland in Pakistan (according to the GLADA program), 1981-2008.

\begin{tabular}{|c|c|c|c|c|}
\hline $\begin{array}{l}\text { Area of degraded } \\
\text { land, } \mathrm{km}^{2}\end{array}$ & $\begin{array}{l}\text { The share of degraded land in } \\
\text { the total area of the country, } \%\end{array}$ & $\begin{array}{c}\text { Share of total world area } \\
\text { of degraded lands, } \%\end{array}$ & $\begin{array}{c}\text { Percentage of population } \\
\text { living on degraded lands, } \%\end{array}$ & $\begin{array}{l}\text { Total biomass loss, } \\
\text { NPPTC/ year }\end{array}$ \\
\hline 20644 & 2.57 & 0.073 & 3.58 & 235711 \\
\hline
\end{tabular}

Note - Compiled by the author based on the source: Paptsov AG Global food security in the context of climate change: monograph / A.G. Paptsov, N.A. Shelamov. M. RAN.- 2018. - 132. 
Table 6 - Cereal production in (Metric tons).

\begin{tabular}{lcc}
\hline Year & Value & Change, $\%$ \\
\hline 2017 & 44097200 & $3.63 \%$ \\
2016 & 42554500 & $3.59 \%$ \\
2015 & 41081682 & $-1.94 \%$ \\
2014 & 41895811 & $4.45 \%$ \\
2013 & 40109711 & $9.90 \%$ \\
2012 & 36496350 & $-7.14 \%$ \\
\hline 2011 & 39304580 & $12.91 \%$ \\
2010 & 34811258 & $-8.74 \%$ \\
\hline 2009 & 38147050 & $7.37 \%$ \\
2008 & 35528100 & $-0.79 \%$ \\
\hline 2007 & 35812200 & $8.43 \%$ \\
\hline
\end{tabular}

Note - Compiled by the author based on the source: Electronic Resource: www.hikersday.cjm/climate/Pakistan.

level with a constant amount of precipitation. Second, an increase in the amount of precipitation by $1 \%$ of the average level, the yield decreases by $0.59 \%$ of its average level at constant air temperature. In this context, climate change is not only a threat to Pakistan but also the entire world's agriculture. This may increase inter-annual and intra-annual variability of river flow. Uncertainty, regarding this effect reducing the area of glaciers on river runoff. The increase in demand for irrigation water due to higher evaporation rates as a result of higher air temperatures and due to reduced availability of water resources per capita.

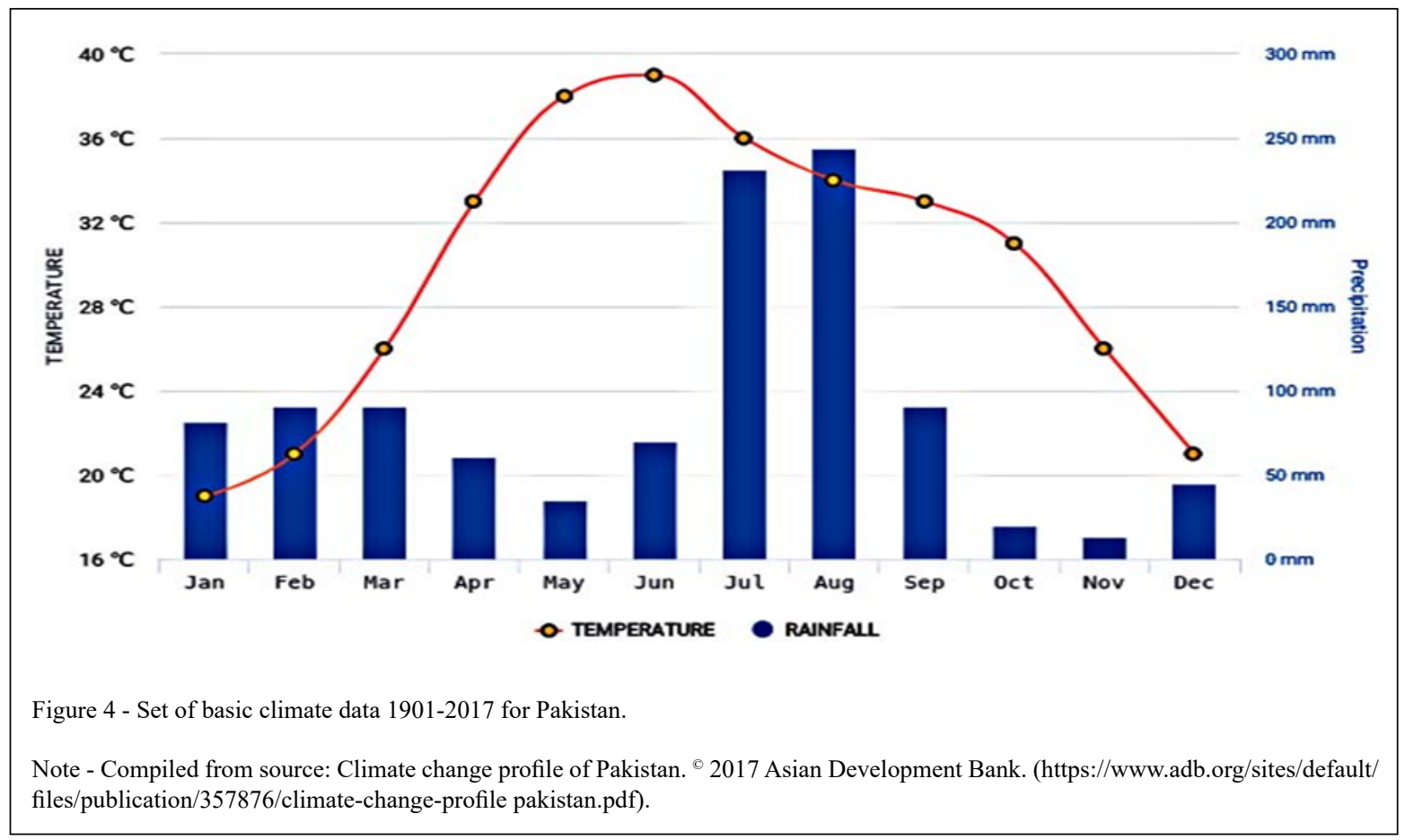

Ciência Rural, v.51, n.8, 2021. 


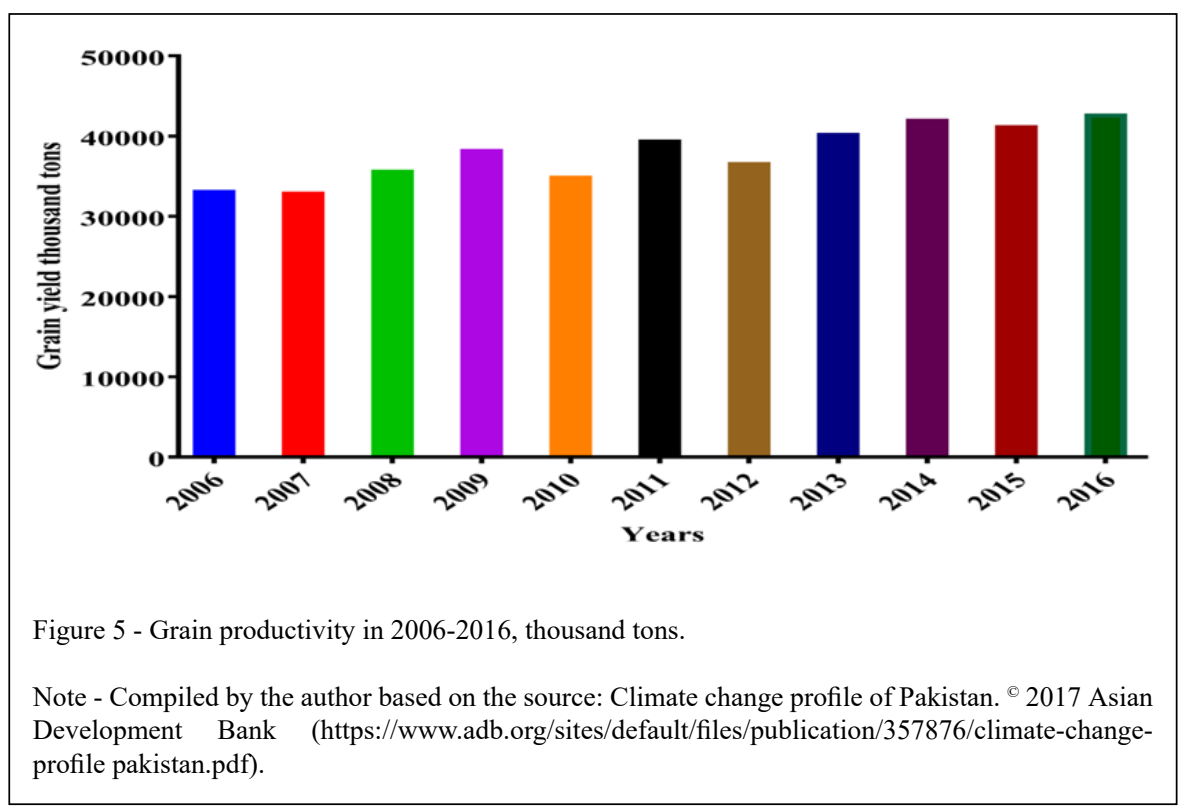

Reducing the volume of reservoirs and imperfect irrigation systems with high water losses reduces crop productivity. An increase in groundwater levels due to poor management of irrigation systems and the lack of drainage facilities. The lack of crossborder infrastructure for flow control and glacier monitoring (AHMAD, 2009).
The analysis of the study suggested some critical results. First, the role of agriculture in the country's economy plays one of the key values. Second, as the systematization of theoretical approaches by the author has shown, ideas about the role of agriculture in social development have always been a reflection of the economic realities of the

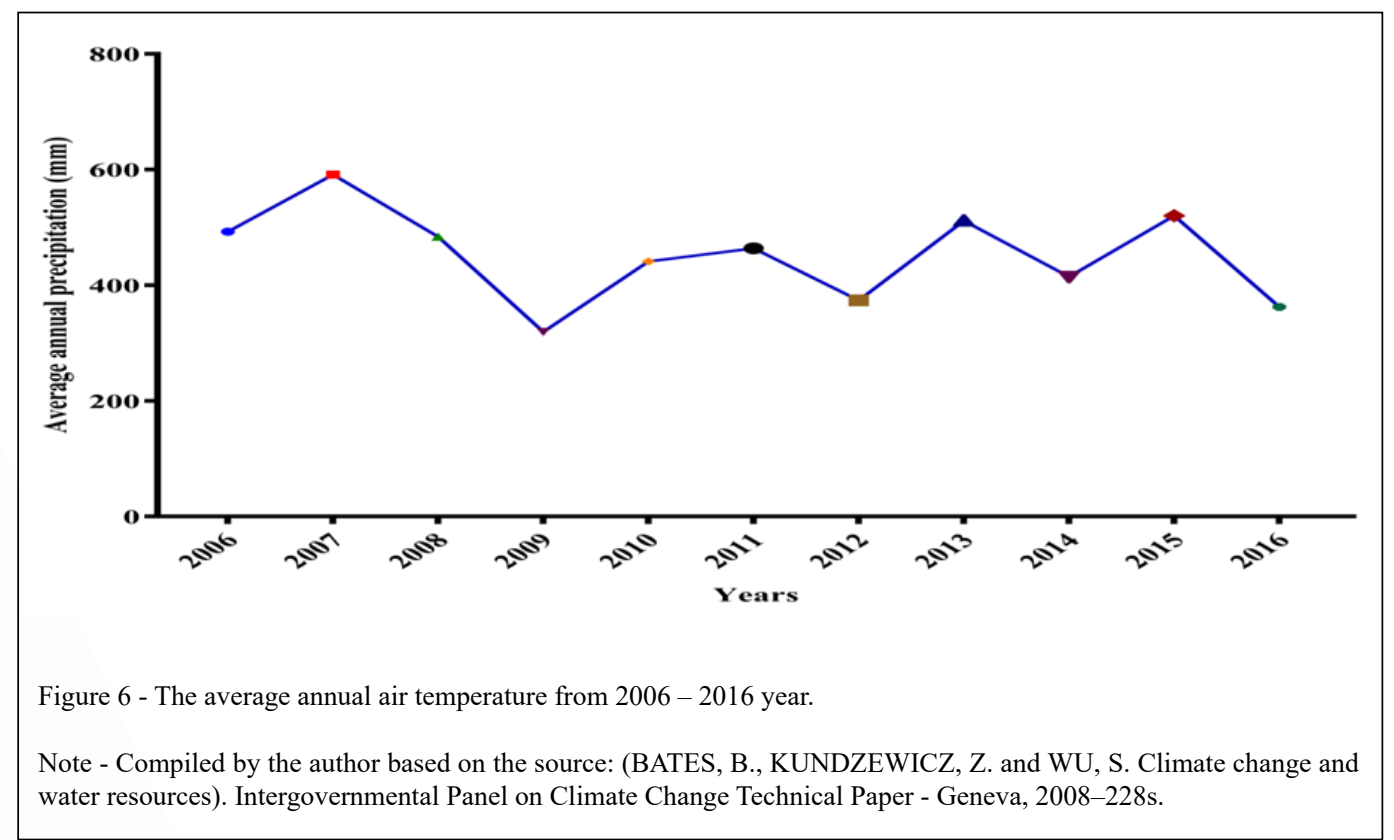

Ciência Rural, v.51, n.8, 2021. 


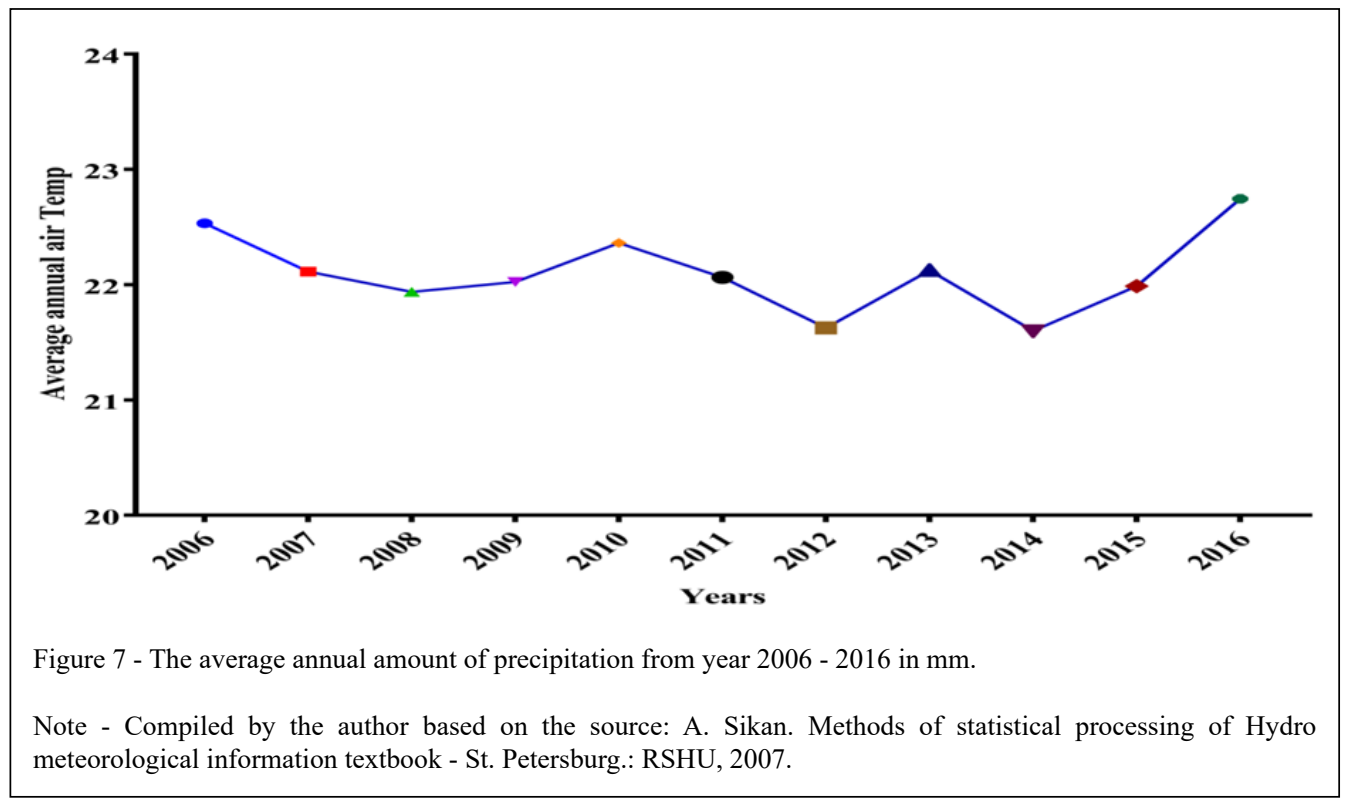

current period and have changed under the influence of technological and socio-economic transformations of the agricultural sector; Thirdly, the development of agriculture is based on the corresponding state agrarian policy. The author considered that the degree of government intervention in agriculture, responding to the aggravation of agricultural markets, the change of technological structures, and the modernization of the social structure of society, has consistently expanded from a "point" irregular impact on the development of an integrated system of state regulation of the industry (V. MOSKALENKO, 2013). In recent decades, Pakistan has faced many catastrophic situations such as political and economic crises, natural disasters, and other conflicts with neighboring countries (STADNIK et al., 2014). Besides these issues, climate change is constantly affecting Pakistan's agricultural sector. Therefore, without developing a scientifically based strategy for developing the industry at all levels of management, it is impossible to overcome the crisis and lay the foundation for the rapid development of the agricultural sector of the economy. Thus, climate change requires the development and adoption of measures to adapt to these changes and mitigate their effects (CHANDIO et al., 2020d; SAMOO, 2011).

\section{CONCLUSION}

This study was developed to check the impact of climate change on the agriculture sector in the context of Pakistan. The specific objectives of this study are to check the impact of change in temperature on the agriculture sector in Pakistan. The second objective of this study is to determine the influence of change in precipitation on the agricultural sector in Pakistan. For this purpose, the two-factor regression model was employed. The results of the study reveal that changes in temperature and precipitation have a negative impact on the agriculture sector in Pakistan. Moreover, this study shows that the agricultural sector highly depends on both these two factors and has a robust association with each other. Furthermore, the agricultural sector is more vulnerable two these two determinants. Therefore, timely adaptation strategies to mitigate these challenges are required.

In modern conditions, when new functions are assigned to global agriculture to ensure sustainable general economic development, the regulatory system receives a new round of development and enters the interstate level, which assumes international coordination of Pakistan's agricultural policy with other states. Thus, farming in most agricultural areas of Pakistan without irrigation is impossible in others it is associated with great risk and brings low yields. The main reason for the degradation of farmland, most strongly associated with global climate change is water and wind erosion of soils. The results obtained are intended to provide a scientific justification for the specialization of agricultural production in the regions of Pakistan and the conduct of the necessary agricultural activities. 


\section{ACKNOWLEDGMENTS}

This study is supported by the General Program of National Natural Science Foundation of China Mechanism of farmer production connection and its Association Research on the Mechanism of Credit Risk Grant No. 71873101.

\section{DECLARATION OF CONFLICT OF INTEREST}

The authors declare no conflict of interest. The founding sponsors had no role in the design of the study; in the collection, analyses, or interpretation of data; in the writing of the manuscript, and in the decision to publish the results.

\section{AUTHORS' CONTRIBUTIONS}

UA and WJ conceived and designed the research. UA collected data and prepared the draft of the manuscript. WJ supervised and provided fund acquisition. UA and JZ performed formal analysis. UA, WJ, JZ, ZO, SF, ZN, and ZAK performed the proofread, edit, revised and approved the final version of the manuscript collectively.

\section{REFERENCES}

AHMAD, S. Water resources and be consistent all first letter lower casManagement in Pakistan - Challenges and future Vision. Paper on the National University of Agricultural Sciences, National Agricultural Research Center, Islamabad. 2009. Available from: <https://www.jstor.org $>$. Accessed: Dec. 09,2020

ALI, U., et al. Determinants of farmers'choice adaptation strategies to climate change: Evidence from Khyber Pakhtunkhwa Pakistan. Pakistan Journal of Agricultural Sciences, v.57, n.3. 2020. Available from: $<$ http://www.pakjas.com.pk>. Accessed: Sep. 02 2020. doi: 10.21162/PAKJAS/20.9988.

BATES, B., KUNDZEWICZ, Z. and WU, S. Climate change and water resources. Intergovernmental Panel on Climate Change technical paper - Geneva, 2008 - 228c. 2008. Available from: $<$ https://www.ipcc.ch>. Accessed: Dec. 09, 2019.

BANK, W. Electricity production from oil, gas and coal sources. 2015. Available from: <https://data.worldbank.org/indicator/ EG.ELC.FOSL.ZS?locations=PK-IR>. Accessed: Jan. 01, 2020.

CHANDIO, A. A., et al. Assessment of formal credit and climate change impact on agricultural production in Pakistan: a time series ARDL modeling approach. Sustainability, v.12, n.13, p.5241. 2020a. Available from: $<$ https://www.mdpi.com>. Accessed: Sep. 03, 2020. doi: 10.3390/su12135241.

CHANDIO, A. A., et al. Short and long-run impacts of climate change on agriculture: an empirical evidence from China International Journal of Climate Change Strategies and Management. 2020b. Available from: <https://www. emerald.com>. Accessed: Sep. 03, 2020. doi: 10.1108/IJCCSM-05-2019-0026.

CHANDIO, A. A., et al. Examining the effects of climate change on rice production: case study of Pakistan. Environmental Sci- ence and Pollution Research, v.27, n.8, p.7812-7822. 2020c. Available from: $<$ https://link.springer.com $>$. Accessed: Sep. 03, 2020. doi: 10.1007/s11356-019-07486-9.

CHANDIO, A. A., et al. Empirical analysis of climate change factors affecting cereal yield: evidence from Turkey. Environmental Science and Pollution Research, p.1-14. 2020d. Available from: <https://link.springer.com>. Accessed: Sep. 03, 2020. doi: 10.1007/s11356-020-07739-y.

CLIMATE AND ANNUAL WEATHER IN PAKISTAN. 19012017. Available from: <www.hikersbay.com/climate/Pakistan. Accessed: Jan. 11, 2020

FAO. FAOSTAT. 2018. Available from: $<$ http://www.fao.org/faostat/en/\#compare>. Accessed: Dec. 25, 2019.

GOP. GOVERNMENT OF PAKISTAN (GOP). Agricultural statistics of Pakistan, 2016-2017. Islamabad Economics Division, Ministry of Food, Agriculture and Livestock, Government of Pakistan, 2017 [P. 40]. 2017a. Available from: <https://www.pbs.gov. pkagri-stat-tables>. Accessed: Dec. 25, 2019.

GOP. GOVERNMENT OF PAKISTAN (GOP). Economic Survey of Pakistan, 2004-2005. Islamabad: Ministry of Finance, Government of Pakistan, Federal Secretariat, 2005. Available from: <https://www.pbs.gov.pkagri-stat-tables $>$. Accessed: Dec. 25,2019 .

GOP. GOVERNMENT OF PAKISTAN (GOP). Agricultural Statistics of Pakistan. Islamabad Economics Division, Ministry of Food, Agriculture and Livestock, Government of Pakistan, 2010-2011. Available from: <https://www.pbs.gov.pk>. Accessed: Dec. 22, 2019.

GOP. GOVERNMENT OF PAKISTAN. Agricultural Statistics of Pakistan. 2012-2017. Islamabad Economics Division, Ministry of Food, Agriculture and Livestock, Government of Pakistan. 2012-2017. Available from: <https://www.pbs.gov.pk>. Accessed: Dec. 22, 2019.

GOP. GOVERNMENT OF PAKISTAN (GOP). Economic Survey of Pakistan, 2012-2013. Islamabad: Ministry of Finance, Government of Pakistan, Federal Secretariat, 2013. Available from: <https://www.pbs.gov.pkagri-stat-tables $>$. Accessed: Dec. 25,2019 .

GOP. GOVERNMENT OF PAKISTAN (GOP). Agricultural statistics of Pakistan, 2016-2017. Islamabad Economics Division, Ministry of Food, Agriculture and Livestock, Government of Pakistan, 2017 [P. 19]. 2017b. Available from: <https://www.pbs.gov. pk>. Accessed: Dec. 22, 2019.

GOP. GOVERNMENT OF PAKISTAN (GOP). Economic Survey of Pakistan, 2016-2017. Islamabad: Ministry of Finance, Government of Pakistan, Federal Secretariat, 2017. 2017c. Available from: $<$ https:// www.pbs.gov.pkagri-stat-tables>. Accessed: Dec. 25, 2019.

GOP. GOVERNMENT OF PAKISTAN (GOP). Agricultural Statistics of Pakistan, 2016-2017. Ministry of National Food Security \& Research (MNFSR)/Pakistan Agricultural Research Council (PARC), Islamabad. 2017d. Available from: <http://www.parc.gov. pk>. Accessed: Dec. 28, 2019.

JANJUA, P. Z., et al. Climate change and wheat production in Pakistan: An autoregressive distributed lag approach. NJAS-Wa- 
geningen Journal of Life Sciences, v.68, p.13-19. 2014. Available from: <https://www.researchgate.net>. Accessed: Sep. 06, 2020. doi: 10.1016/j.njas.2013.11.002.

KAHLOWN, M. A.; A. MAJEED. Water-resources situation in Pakistan: challenges and future strategies. Water Resources in the South: present scenario and future prospects, v.20, p.33-45. 2003. Available from: <http://www.sciencevision.org.pk $>$. Accessed: Sep. 07, 2020.

KAMENEV S.N. Economic development of Pakistan (19472012): Macroeconomic Analysis / Institute of Oriental Studies, RAS. - M .: IW RAS; Center for strategic conjuncture, 2014. 384p. 2014. Available from: <https://elibrary.ru>. Accessed: Dec. $28,2019$.

KHETRAN, M. S. Economic connectivity: Pakistan, China, West Asia and Central Asia. Strategic Studies, v.36, n.4, p.61-76. 2016. Available from: $<$ http://issi.org.pk>. Accessed: Sep. 07, 2020

KISELEVA O. Stabilization of the financial situation of agricultural enterprises // AIC: economics, management - №7 - 2003 - p.70. 2003. Available from: <http://www.library.omsu.ru>. Accessed: Dec. 18, 2019

KURMANBAEV S.K., A. M. M. Justification of price and financial and credit mechanisms for the regulation of the agro-food market // Materials of the international scientific-practical conference "Prospects for the production and processing of agricultural raw materials in a market economy" Semey, 2015 - p.234. 2015. Available from: <https://www.kaznu.kz>. Accessed: Dec. 25, 2019.

MAAS, A., et al. Climate change and the water-energy agriculture nexus in Central Asia. Adelphi: Berlin, Germany. 2011. Available from: $<$ https://www.adelphi.de $>$. Accessed: Jan. 02, 2020.

MALASHIKHINA N. N. Risk - management. - Rostov on Don Publisher: "Phoenix", 2014. - p.224. 2014. Available from: <http:// www.fa.ru>. Accessed: Dec. 25, 2019.

MOHAMMED, A. Features of the water regime of the Indus River // St. Petersburg, [p.14]. 2018. Available from: <https:// hess.copernicus.org >. Accessed: Dec. 20, 2019. doi: 10.5194/hess16-1063-2012.

PAKISTAN, C. C. P. O. Climate change profile of Pakistan. 2017 Asian Development Bank. 2017. Available from: <https:// www.adb.org/sites/default/files/publication/357876/climatechange-profile pakistan.pdf $>$. Accessed: Jan. 07, 2020

PAPTSOV A. G. Global food security in the context of climate change: monograph / A.G. Paptsov, N.A. Shelamov. M .: RAS. - 2018. -p.132. 2018. Available from: <http://www.ras.ru>. Accessed: Dec. 28, 2019.

POINTNER, W.; D. RITZBERGER-GRÜNWALD. Climate change as a risk to financial stability. Financial Stability Report, n.38, p.30-45. 2019. Available from: $<$ https://ideas.repec.org $>$. Accessed: Jan. 07, 2020

PRAVEEN, B.; P. SHARMA. A review of literature on climate change and its impacts on agriculture productivity. Journal of Public Affairs, v.19, n.4, p.e1960. 2019. Available from: $<$ https://www.researchgate.net $>$. Accessed: Sep. 08, 2020. doi: 10.1002/pa. 1960

SAMOO, A. N. Safeguards for the poor // Economic and Business Review. Karachi, 04/25/2011. 2011. Available from: <http:// www.qal.org.pk>. Accessed: Jan. 02, 2020.

SARKER, M. A. R., et al. Exploring the relationship between climate change and rice yield in Bangladesh: An analysis of time series data. Agricultural Systems, v.112, p.11-16. 2012. Available from: <https://www.sciencedirect.com>. Accessed: Sep. 05, 2020. doi: 10.1016/j.agsy.2012.06.004.

SEDELEV B. V. Regression models and methods for estimating the parameters and structure of economic processes: Study Guide / Edited by V.V. Kharitonov. M .: MEPhI, 2009. p.240. 2009. Available from: $<$ https://www.twirpx.com>. Accessed: Dec. 09, 2019.

SHAH, I. H.; H. S. PARK. Chronological change of resource metabolism and decarbonization patterns in Pakistan: Perspectives from a typical developing country. Journal of Industrial Ecology. 2020. Available from: <https://onlinelibrary.wiley.com>. Accessed: Sep. 05, 2020. doi: 10.1111/jiec.13060.

SIKAN A. V. Methods of statistical processing of hydrometeorological information. Textbook - SPb .: RSU, 2007. -p.279. 2007. Available from: <https://www.geokniga.org >. Accessed: Dec. 09, 2020.

STADNIK, A. T., et al. The Evolution of state support for Agriculture: Foreign Experience // - Yekaterinburg, 2014. 2014. Available from: $<$ https://cyberleninka.ru $>$. Accessed: Jan. 09, 2020.

STOEFFLER, Q., et al. The spillover impact of index insurance on agricultural investment by cotton farmers in burkina faso. National Bureau of Economic Research. 2020. Available from: <https:// www.nber.org >. Accessed: Sep. 05, 2020. doi: 10.3386/w27564. V. MOSKALENKO, P. T. Pakistan's Strength and Weaknesses M.: Carnegie Center, 2013. - p.75. 2013. Available from: $<$ https:// carnegieendowment.org>. Accessed: Jan. 11, 2020.

ZAIED, Y. B.; N. B. CHEIKH. Long-run versus short-run analysis of climate change impacts on agricultural crops. Environmental Modeling \& Assessment, v.20, n.3, p.259-271. 2015. Available from: <https://link.springer.com>. Accessed: Sep. 05, 2020. doi: 10.1007/s10666-014-9432-4.

ZHU, Y., et al. A survey: obstacles and strategies for the development of ground-water resources in arid inland river basins of Western China. Journal of Arid Environments, v.59, n.2, p.351367. 2004. Available from: <https://www.sciencedirect.com>. Accessed: Sep. 05, 2020. doi: 10.1016/j.jaridenv.2003.12.006. 